ISSN: $1679-3013$

\title{
CIRCULATION AND HEAT BUDGET IN A REGIONAL CLIMATOLOGICAL SIMULATION OF THE SOUTHWESTERN TROPICAL ATLANTIC
}

\author{
Marcus SILVA ${ }^{\mathbf{1}, 4,5}$ \\ Moacyr ARAUJO $\mathbf{1}^{1,4}$ \\ Jacques SERVAIN ${ }^{2,4}$, \\ Pierrick PENVEN ${ }^{3}$
}

\begin{abstract}
Surface and vertical thermal structures, heat budget in the surface mixing layer, and mass transports are explored in the south-western tropical Atlantic $\left(5^{\circ} \mathrm{S}-25^{\circ} \mathrm{S} /\right.$ $20^{\circ} \mathrm{W}-47^{\circ} \mathrm{W}$ ). That region, where part of the South Equatorial Current (SEC) enters at its eastern border, is of prime interest by feeding many western boundary currents along the eastern Brazilian edge, and by contributing to the climatic variability over the Northeast Brazil. The Regional Ocean Model System (ROMS) is used here to simulate a seasonal cycle of the ocean circulation with an isotropic horizontal grid resolution of $1 / 12^{\circ}$ and 40 terrain-following layers. Such a high-resolution regional model allows illustrating the complexity of meso-scales phenomena which occur in that region. Model results are compared with the very first annual series of observed thermal profiles available in the region thanks to the three PIRATA-SWE moorings recently deployed. Simulated thermal structure at the upper ocean layers agrees with in-situ data set. Seasonal evolutions of atmospheric and oceanic balances involving in the mixing layer heat budget are locally discussed. The magnitude of oceanic components (mainly the vertical diffusion and the horizontal advection) is about of the same order than of atmospheric forcing, and practically always opposes to it, with some local and seasonal timing differences. Simulated meridional transports across three zonal sections extending from continent to PIRATA sites provide new insight in the knowledge of the western boundary current system. Another section running along the PIRATA-SWE array indicates how the divergence of SEC is complex. This result encourages the need and future expansion of the observational PIRATA array system in that region.
\end{abstract}

Keywords: South Western Tropical Atlantic, Upper Ocean layers, Ocean heat budget, PIRATA-SWE moorings, ROMS

\section{RESUMO}

Este trabalho apresenta estruturas de verticais de temperatura, balanço de calor na camada de mistura superficial e transporte de massa na fronteira sudoeste do Atlântico tropical $\left(5^{\circ} \mathrm{S}-25^{\circ} \mathrm{S} / 20^{\circ} \mathrm{W}-47^{\circ} \mathrm{W}\right)$. Nesta região parte da Corrente Sul-equatorial entra por sua borda leste, originando várias correntes de fronteira oeste ao longo da costa brasileira agindo sobre a variabilidade climática do Nordeste do Brasil. O Modelo Matemático ROMS (Regional Ocean Model System) é utilizado aqui para simular ciclos sazonais de circulação oceânica com uma malha horizontal isotrópica de $1 / 12^{\circ}$ e com 40 camadas sigma, que acompanham a morfologia de fundo. Esta aplicação regional de alta resolução permite ilustrar complexos fenômenos de meso-escala. Resultados de simulação são comparados com as primeiras séries temporais de perfis verticais de temperatura observadas nesta região, graças às três bóias recentemente fundeadas dentro do Programa PIRATA-SWE. Estruturas verticais simuladas estão em concordância com as medições realizadas. Evoluções sazonais dos balanços de calor superficiais e laterais dentro da camada de mistura são discutidas localmente. A intensidade de componentes oceânicas (principalmente a difusão vertical e a advecção horizontal) são da mesma ordem de grandeza do forçante atmosférico, e praticamente opostas nas

Contatos: ${ }^{1}$ Laboratório de Oceanografia Física Estuarina e Costeira, Departamento de

Oceanografia da Universidade Federal de Pernambuco (LOFEC/DOCEAN/UFPE), Av. Arquitetura s/n, 50740-550, Cidade Universitária, Recife, PE, Brazil.

2 Institut de Recherche pour le Développement (IRD), UMR-182, Paris, France. Current affiliation at Fundação Cearense de Meteorologia e Recursos Hídricos (FUNCEME), Fortaleza, CE, Brazil

${ }^{3}$ Institut de Recherche pour le Développement (IRD), UMR-097, Brest, France

${ }^{4}$ GOAT- Grupo de Oceanografia Tropical, http://www.goat.fis.ufba.br/

${ }^{5}$ Corresponding author address: marcus@ufpe.br 
mesmas localidades em diferentes estações. O transporte meridional simulado, através das três seções zonais, que se extendem da costa até cada uma das três boias PIRATASWE, dispõe um novo conhecimento do sistema de correntes superficial da borda oeste. Outra seção, ao longo das três bóias PIRATA-SWE, indica como é complexa a divergência da SEC. Este trabalho encoraja a necessidade de expansão do conjunto de bóias do programa PIRATA ao longo desta região.

Palavras-chave: Fronteira Sudoeste do Atlântico Tropical, Camada superficial do Oceano, balanço de calor, PIRATA-SWE, ROMS.

\section{INTRODUCTION}

The southwestern tropical Atlantic is a particularly interesting ocean area acting as a cradle of multiple oceanic-weather forcings of great importance. This is the region of oceanic divergence of the South Equatorial Current (SEC) in a northern and a southern branches along the Brazilian coastline. Towards the north, the northern branch of the SEC termination forms the North Brazil Under Current-North Brazil Current (NBUC-NBC) system (Silveira et al., 1994; Stramma et al., 1995; Rodrigues et al., 2007), one of the most powerful western boundary current in the world. As part of the Atlantic Subtropical Cell (STC), this is the preferential way for connecting the subduction regions of the subtropical South Atlantic and the eastern equatorial and Equatorial Undercurrent, which in turn feed the equatorial upwelling systems (Malanote-Rizolli et al, 2000; Schott et al., 2005). This region is also an important highway for the Atlantic Meridional Overturning Circulation (MOC), where the southward flow of deeper North Atlantic Deep Water (NADW) is compensated by the northward transfer of near surface warm and intermediate waters, as well as the Antarctic Bottom Water (Lumpkin \& Speer, 2003; Ganachaud, 2003).

After the bifurcation close to Brazilian shelf, the SEC also supplies the Brazil Current (BC) propagating southward along the coast of Brazil (Stramma, 1991; Peterson \& Stramma, 1991; Stramma et al., 1995). Being in the region of the southeast trade winds and the South Atlantic Convergence Zone (SACZ), interactions between sea surface temperature (SST) and the easterly atmospheric circulation may play a significant role in local climate fluctuations of Northeast Brazil, a region affected by intermittence of severe droughts or floods (Moura \& Shukla, 1981; Rao et al., 1993).

We are mainly interested here on the seasonal and intra-seasonal ocean dynamics in the region of the southernmost extension of the westward SEC, the SSEC. First results obtained from a versatile new generation state-of-the-art Regional Ocean Modeling System (ROMS) are analyzed in connection with scarce available long-term observations. Indeed, continuously subsurface observations in this study region were non-existent until the recently deployed ATLAS buoys in August 2005 as part of the South West Extension of the Prediction Research moored Array in the Tropical Atlantic (PIRATA-SWE) which runs along the edge of Brazil's coastline south of the equator (Fig. 1). Therefore, this work intends also to refine the arguments for a continuation, and even the extension, of the oceanic observing system in this region.

The main characteristics of ROMS and conditions of the seasonal simulation are presented in the next Section, while Section 3 gives some details on the PIRATA-SWE data set. Illustrations of the high-resolution simulations are shown in Section 4, where, simulated and observed thermal structures in the upper layers are compared. Also in Section 4 we provide simulated seasonal variation of oceanic components of heat content in the mixing layer, as well as mass and heat transports across three zonal sections and a fourth section along the PIRATA-SWE sites. The last Section presents the conclusion and perspectives.

\section{METHODOLOGY}

\section{The ROMS modelling}

The ROMS solves the free surface, primitive equations in a Earth-centered rotating environment, based on the classical Boussinesq approximation and hydrostatic vertical 
SILVA; ARAUJO; SERVAIN; PENVEN. Circulation and heat budget in a regional climatological simulation of the Southwestern Tropical Atlantic.

momentum balance (Shchepetkin \& McWilliams, 2005). The model considers coastlineand terrain-following curvilinear coordinates, which allows minimizing the number of dead points in computing the solution. The boundary conditions for the model are then appropriate for an irregular solid bottom and coastline, free upper surfaces and openocean sides away from the coastline. These include the forcing influences of surface wind stress, heat and water fluxes, coastal river inflows, bottom drag, and open-ocean outgoing wave radiation and nudging towards the specified basin-scale circulation. The model has been previously adapted in different regions of the world ocean (Haidvogel et al., 2000; Malanotte-Rizzoli et al., 2000; She \& Klinck, 2000; Penven et al., 2000, 2001; McCready \& Geyer, 2001; Lutjeharms et al., 2003).

Upstream advection in ROMS is treated with a third-order scheme that enhances the solution through the generation of steep gradients as a function of a given grid size (Shchepetkin \& McWilliams, 1998). Unresolved vertical sugbrid-scale processes are parameterized by an adaptation of the non-local K-profile planetary boundary layer scheme (Large et al., 1994). A complete description of the model may be found in Haidvogel et al. (2000), and Shchepetkin \& McWilliams (2005).

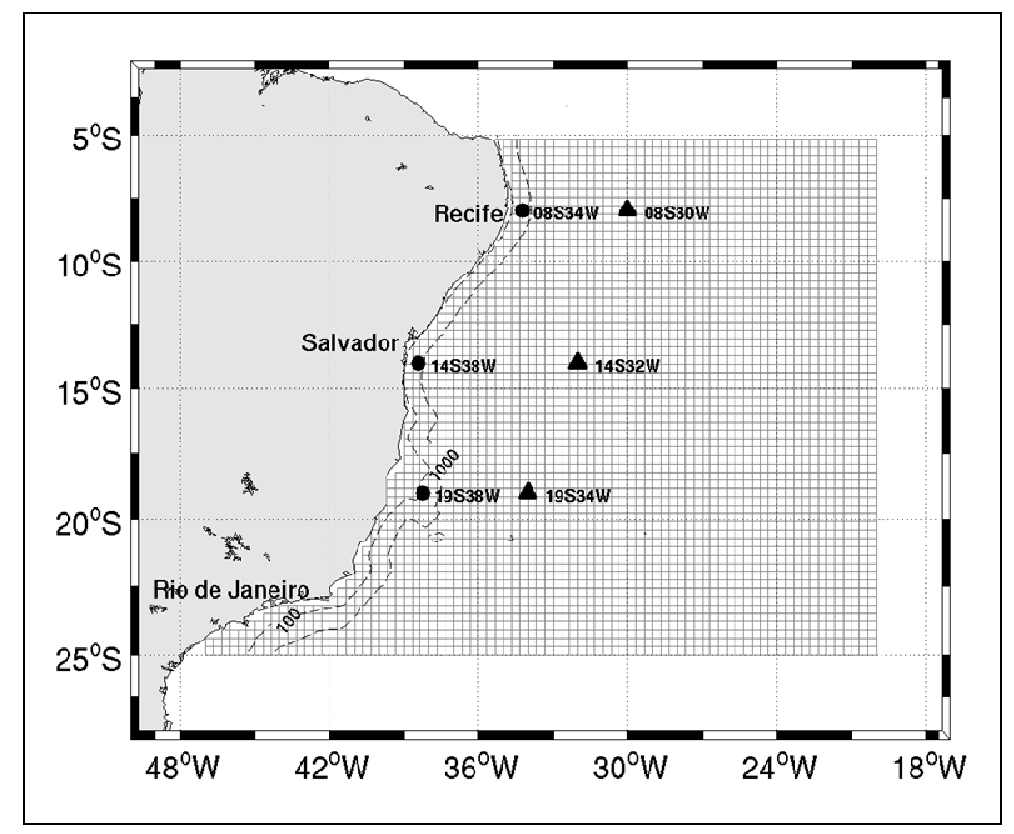

Figure 1. Model domain (dashed lines) with the PIRATA-SWE locations (filled triangles) and three sites located along the western boundary region closer to the Brazilian edge (filled circles). Near shore $100 \mathrm{~m}$ and $1000 \mathrm{~m}$ isobaths are plotted.

The study case presented here involves the open ocean area near the Brazilian coast. The integration domain is comprised within $5^{\circ} \mathrm{S}$ and $25^{\circ} \mathrm{S}, 20^{\circ} \mathrm{W}$ and $47^{\circ} \mathrm{W}$ (Fig. 1 ). An isotropic $1 / 12^{\circ}$ horizontal grid results in $323 \times 249$ horizontal mesh cells. Vertical discretization has 40 levels. Bottom topography was derived from a 2 ' resolution database ETOPO2 (Smith \& Sandwell, 1997), and a slope parameter $r=\nabla h / h<0.20$ is used to prevent errors in the computation of pressure gradient (Haidvogel et al., 2000). At the three open boundaries (north, east and south) an active, implicit, upstream biased radiation condition connects the model solution to the surrounding ocean (Marchesiello et al., 2001). Horizontal Laplacian diffusivity inside the integration domain is zero, and a 12-points smooth increasing is imposed (up to $10^{4} \mathrm{~m}^{2} \mathrm{~s}^{-1}$ ) in sponge layers near open ocean boundaries. The model equations are subjected to no-slip boundary conditions along the coastline. A basin scale seasonal hydrology derived from World Ocean Atlas 2001 (WOA2001) database (monthly climatology at $1^{\circ} \times 1^{\circ}$ resolution) (Conkright et al., 2002) is used to infer thermohaline properties (temperature and salinity) and geostrophic currents at the open boundaries. The oceanic circulation was forced at the sea surface by winds, heat fluxes and fresh water fluxes derived from the 
Comprehensive Ocean-Atmosphere Data Set (COADS) monthly fluxes data at $0.5^{\circ} \times 0.5^{\circ}$ resolution (da Silva et al., 1994).

The model runs from a state of rest for 10 years. The steady state is statistically achieved after a spin-up period of about one year. Except for snapshots serving for illustration of high-frequency simulations (Section Instantaneous SST evaluation), all the numerical results examined here correspond to averages of the last two years of simulation.

\section{The PIRATA-SWE dataset}

PIRATA is a ten-years ocean-meteorological observing system which contributes to the operational climate survey of the global ocean (Servain et al., 1998; Bourlès et al., 2008). PIRATA is the result of an international scientific cooperation gathering Brazil, France and the United States of America. Its main scientific motivation is to monitor, describe and understand the two main modes of climatic variability over the tropical Atlantic which are the equatorial and the meridional modes (Servain et al., 1998). Based on this rational, the original array configuration is presently composed by 10 ATLAS moorings (Hayes et al., 1991) along the equatorial line $\left(35^{\circ} \mathrm{W}, 23^{\circ} \mathrm{W}, 10^{\circ} \mathrm{W}\right.$ and $\left.0^{\circ} \mathrm{E}\right)$ and two meridional lines, one along the $38^{\circ} \mathrm{W}$ meridian $\left(4^{\circ} \mathrm{N}, 7^{\circ} \mathrm{N}, 12^{\circ} \mathrm{N}\right.$ and $\left.15^{\circ} \mathrm{N}\right)$, and the other along the $10^{\circ} \mathrm{W}$ meridian $\left(0^{\circ} \mathrm{N}, 6^{\circ} \mathrm{S}\right.$ and $\left.10^{\circ} \mathrm{S}\right)$. Brazil and France are responsible for the yearly sea maintenance of the array, while USA provides the ATLAS material and process the raw data. Daily transmissions of the first $500 \mathrm{~m}$ of ocean temperature (11 levels) and salinity (4 levels), and the meteorological main variables at the sea surface, are ensured thanks to the ARGOS satellite system, and immediately available on the Web after first validation (http://www.pmel.noaa.gov/ pirata/).

Once assured the success of the PIRATA original array (Bourlès et al., 2008), and in order to complete the necessary set of observations to understand more in details the seasonal and inter-annual variability over specific areas in the tropical Atlantic, it was decided to extend the original mooring array. Three extensions were proposed: a first one over the southwest tropical basin (along the Brazilian coast), a second one over the southeast basin (along the African coast, south of the Equator), and a third one over the northern and northeast basin (again along the African coast). Brazil took alone the responsibility for implementing the south-western extension. Obviously, the main goal of this project, the PIRATA South West Extension (PIRATA-SWE), is primarily to help in the forecasting of the Brazilian climate, especially over the Northeast Brazilian region.

Three sites for the ATLAS mooring were chosen for the PIRATA-SWE (Fig. 1) according to scientific arguments (Nobre et al., 2005, 2008): (i) $8^{\circ} \mathrm{S}-30^{\circ} \mathrm{W}$ in connection with the $0^{\circ} \mathrm{N}-10^{\circ} \mathrm{W}$ site of the PIRATA's backbone, (i.e. the equatorial Atlantic warm pool vs. the cold tongue complex); (ii) $14^{\circ} \mathrm{S}-32^{\circ} \mathrm{W}$ in connection with the sSEC flow (properties and heat flux transport variability); (iii) $19^{\circ} \mathrm{S}-34^{\circ} \mathrm{W}$ in connection with the SACZ (relations to the oceanic heat flux changes). Obviously, the PIRATA-SWE array only addresses the changes in the thermohaline structure within the SEC's flow into the bifurcation region. The understanding of changes in the partition between the NBC and the BC at the SEC bifurcation is out of the PIRATA-SWE objectives.

The three ATLAS buoys of the PIRATA-SWE were launched during the second half of August 2005, thus the time series analysed here cover the first 2.5 years of dataset, from September 2005 to February 2008. With the exception of a four-month interruption of the $8^{\circ} \mathrm{S}-32^{\circ} \mathrm{W}$ site due to anchoring problems (the buoy's nylon cable sheared off after ten months of deployment), the buoys reported daily with nearly $100 \%$ of data return. In this study we are using the daily observed PIRATA-SWE data for temperature $(0 \mathrm{~m}$, $20 \mathrm{~m}, 40 \mathrm{~m}, 60 \mathrm{~m}, 80 \mathrm{~m}, 100 \mathrm{~m}, 120 \mathrm{~m}, 140 \mathrm{~m}, 180 \mathrm{~m}, 300 \mathrm{~m}, 500 \mathrm{~m}$ ) operationally obtained on the Web at the PMEL/NOAA address (http://www.pmel.noaa.gov/pirata/).

\section{RESULTS AND DISCUSSION}

Thanks to its refined spatial resolution $\left(1 / 12^{\circ}\right.$ in latitude and longitude; 40 vertical levels) one should expect that ROMS resolves the meso-scale dynamics in the region, 
SILVA; ARAUJO; SERVAIN; PENVEN. Circulation and heat budget in a regional climatological simulation of the Southwestern Tropical Atlantic.

not sufficiently permitted when using OGCMs with larger grids. Thus, as a preliminary test (Section Instantaneous SST evaluation), we evaluate the high-resolution spatial model accuracy by comparing two extreme seasonal model SST snapshots with examples of high-frequency SST patterns provided by satellite measurements. A second type of verification (Section Seasonal evaluation of the heat content) is to validate the simulated annual cycle of temperature and heat content in the mixing layer depth (MLD). The PIRATA-SWE observations are then used for a rough local thermal evaluation of the model within the first $500 \mathrm{~m}$ depth. Because the availability of the PIRATA observations is only 2.5-years long, we cannot focus the present study on inter-annual variability. Such an inter-annual comparison will be only possible when we will have sufficient years of measurement. As an early application of ROMS, a third type of verification (Section Oceanic dynamics vs. atmospheric forcing) is to use the simulated results in order to insight our knowledge in the seasonal variation of the main oceanic dynamics components which are at the origin of the annual SST change in that area. Finally, a fourth type of interest (Section Mass transports across sections) is to look at the yearly averaged oceanic transport simulated by ROMS across zonal sections at the three PIRATA buoy latitudes, as well as a fourth section along these buoys locations.

\section{Instantaneous SST evaluation}

As first illustrations of the model simulation, we present the SST patterns for the two mid-month September and March, i.e. during two extreme seasonal conditions. These figures show mainly a seasonal meridional change in SST along the South Atlantic western boundary. The so-called South Atlantic Warm Pool (SAWP), marked by high SST values $\left(>27^{\circ} \mathrm{C}\right)$, extends off the coastline from the equator to about $12^{\circ} \mathrm{S}$ during austral winter (e.g. September, Fig. 2a) which includes the region of the northern PIRATA buoy only. Six months later, during austral summer (e.g. March, Fig. 2b), these high SST values invade the whole studied zone, and warmer waters now bath the three PIRATA buoys. In connection to that seasonal meridional extension, the SAWP pattern records seasonal zonal changes, with a more alongshore location during summer. The seasonal extension of the colder waters $\left(<22^{\circ} \mathrm{C}\right)$ in the open ocean at the southern limit of the study domain follows the same meridional progression as that of the SAWP. These cold waters are even rejected out of the southern limit of the studied domain during March, except just along the coastline where they remain stationary in the south of $16^{\circ} \mathrm{S}$ during all the year (Ikeda \& Stevenson, 1978; Carbonel, 2003). As also illustrated by these figures it is noted that ROMS succeeds in resolving meso-scale dynamical processes such as frontal structures or filaments.
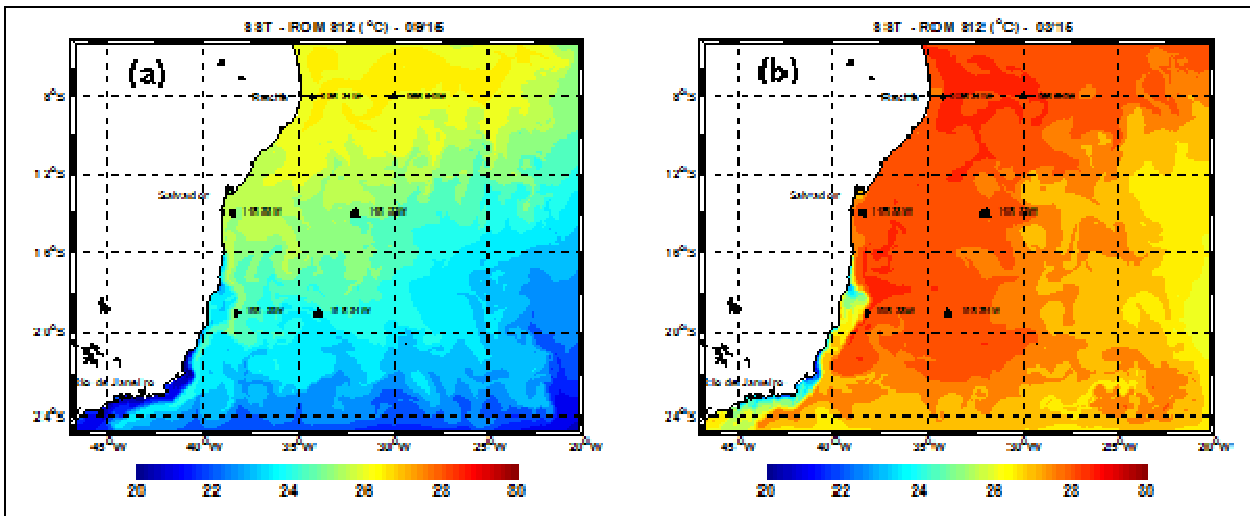

Figure 2. Horizontal distribution of SST obtained from ROMS in mid-September (a) and mid March (b). 


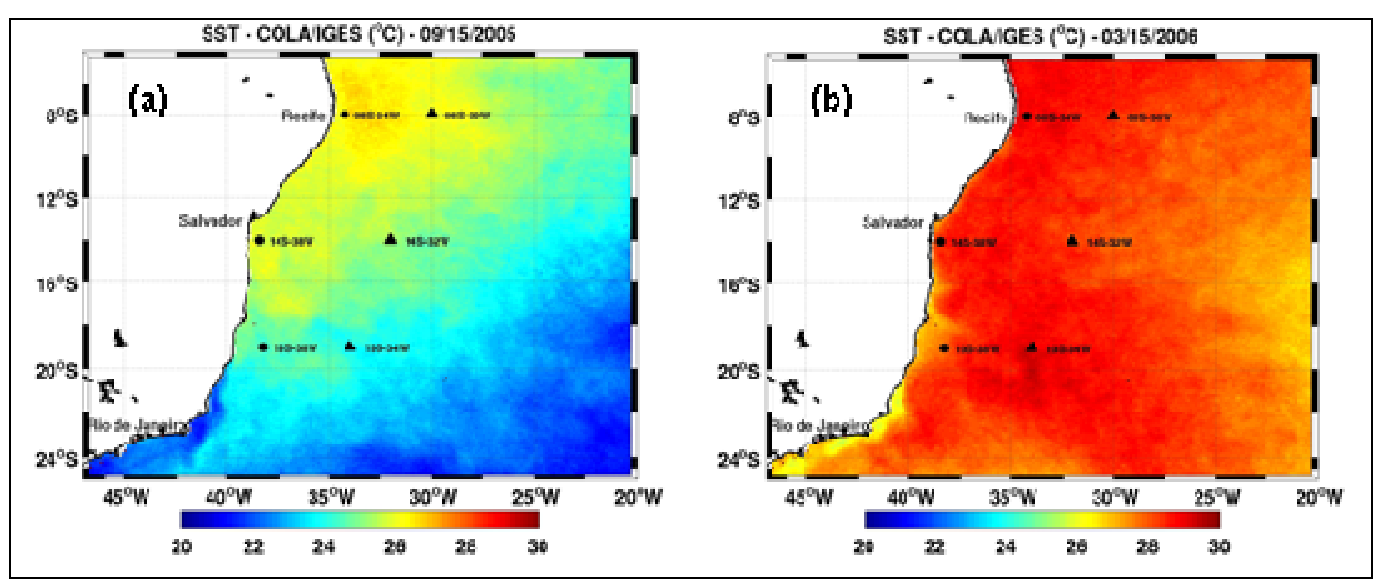

Figure 3. Horizontal distribution of SST obtained from observed satellite data on 15 September 2005 (a) and 15 March 2006 (b).

These phenomena, which are particularly visible at the frontier between warm and cold waters on the ROMS results (Figs. $2 a, b)$ when using a $1 / 12^{\circ}$ resolution $(=9.25 \mathrm{~km}$ ), appear also (slightly more diffuse) on two examples of daily observed SST by satellite using also 9,25 km resolution (GODAE High Resolution Sea Surface Temperature Pilot Project - GHRSST-PP, 2007): one in September 15, 2005 (Fig. 3a), the other one in March 15, 2006 (Fig. 3b). Because several individual images are used to estimate the satellite SST (a necessary process due to the cloud covers) the mesoscale structures seem damped when compared to the model instantaneous SST outputs

\section{Seasonal evaluation of the heat content}

Figures $4 a, b, c$ provide the seasonal variations of the $0-500 m$ temperature for the three PIRATA-SWE locations $\left(08^{\circ} \mathrm{S}-30^{\circ} \mathrm{W}, 14^{\circ} \mathrm{S}-32^{\circ} \mathrm{W}\right.$ and $\left.19^{\circ} \mathrm{S}-34^{\circ} \mathrm{W}\right)$. These Hovmüller diagrams show the ROMS simulated temperature (dashed contours), superimposed to daily observed in-situ data (shaded colors) during the first yearly recording of PIRATASWE network (September 2005 to February 2008). No-shaded parts mean missing PIRATA values. A fairly agreement between ROMS and PIRATA observations is noted, definitely more satisfactory than using an OGCM, even when forced by inter-annual surface fluxes (e.g. Nobre et al., 2008). ROMS reproduces the tightening of the thermocline for the most equatorial PIRATA site $\left(08^{\circ} \mathrm{S}-30^{\circ} \mathrm{W}\right)$, and, on the contrary, the relaxation of that vertical gradient for the two southern sites. Of great interest also is the apparent capacity for ROMS to simulate intraseasonal variations of the thermocline depth, which clearly occur for the central and southernmost locations on the in-situ data within a 3-4 month periodicity 
SILVA; ARAUJO; SERVAIN; PENVEN. Circulation and heat budget in a regional climatological simulation of the Southwestern Tropical Atlantic.

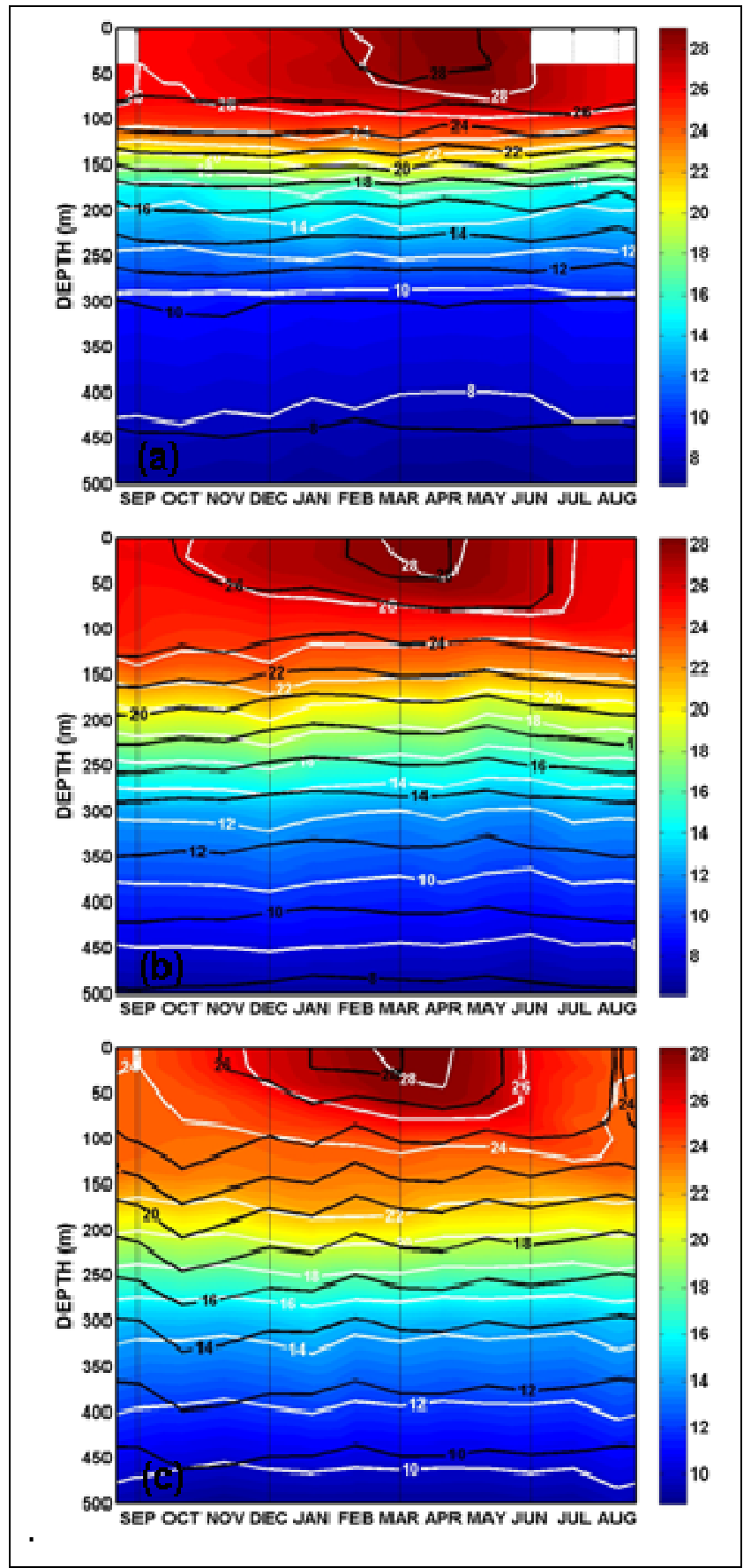

Figure 4. Comparison of the monthly mean vertical temperature distribution $\left({ }^{\circ} \mathrm{C}\right)$ provided by ROMS (black dashed contours) with monthly mean for the period of September 2005 to February 2008 of the three PIRATA-SWE buoys (colour shading and white lines) extending from surface down to $500 \mathrm{~m}$. The four vertical black thin lines correspond to September $15^{\text {th }}$, December $15^{\text {th }}$, March $15^{\text {th }}$ and June $15^{\text {th }}$, . (a) $8^{\circ} \mathrm{S}-30^{\circ} \mathrm{W}$; (b) $14^{\circ} \mathrm{S}-32^{\circ} \mathrm{W}$; (c) $19^{\circ} \mathrm{S}-34^{\circ} \mathrm{W}$.

This is particularly evident on the $19^{\circ} \mathrm{S}-34^{\circ} \mathrm{W}$ site (Fig. 4c). These observed variabilities can be partially explained in terms of ocean adjustment to disturbances in the buoyancy field due to the propagation of barotropic Kelvin waves. It causes vertical displacement of isopycnals and propagates with the coastal boundary on the left in the southern hemisphere. When remembering that the present run is only forced by climatological fluxes, that lets consider a promising accuracy of the intra-seasonal phenomena when the ROMS will be forced in inter-annual mode.

Detailing the preceding discussion, monthly mean temperature profiles $(0-500 \mathrm{~m})$ 
observed by PIRATA-SWE array during September, December, March and June are compared to ROMS outputs for the same calendar months (Figs. 5a,b,c,d). As shown previously, and though climatically forced, the vertical distribution of the simulated temperature is in fairly agreement with the field measurements. In subsurface ( $z$ $>100 \mathrm{~m})$ the best resemblance $\left(\Delta<\left|0.5^{\circ} \mathrm{C}\right|\right)$ occurs for the PIRATA -SWE northernmost site $\left(8^{\circ} \mathrm{S}-30^{\circ} \mathrm{W}\right)$ in March. Such weak difference between model and observation is noted in September for that site in the shallow $(0-100 \mathrm{~m})$ and deeper $(300-500 \mathrm{~m})$ waters. Larger differences $\left(\sim 1\right.$-to- $\left.2^{\circ} \mathrm{C}\right)$, noted below $200 \mathrm{~m}$ for the southern site $\left(14^{\circ} \mathrm{S}-32^{\circ} \mathrm{W}\right)$ in March, as the two other sites for all months plotted, as well as, upper $100 \mathrm{~m}$ to $8^{\circ} \mathrm{S}-30^{\circ} \mathrm{W}$ in June, only, continue to be very acceptable taking into account that the ROMS is running here according to a climatic forcing. Of special interest is the very well reproduced MLD for the three PIRATA sites, whether during warm season $(\sim 20-30 \mathrm{~m}$ in March), or cold season ( $\sim 80-100 \mathrm{~m}$ in September). SST values provided by the model are close to the PIRATA observations, except in September for the southern location, obviously subjected to larger inter-annual variability (see also Fig. 3a).
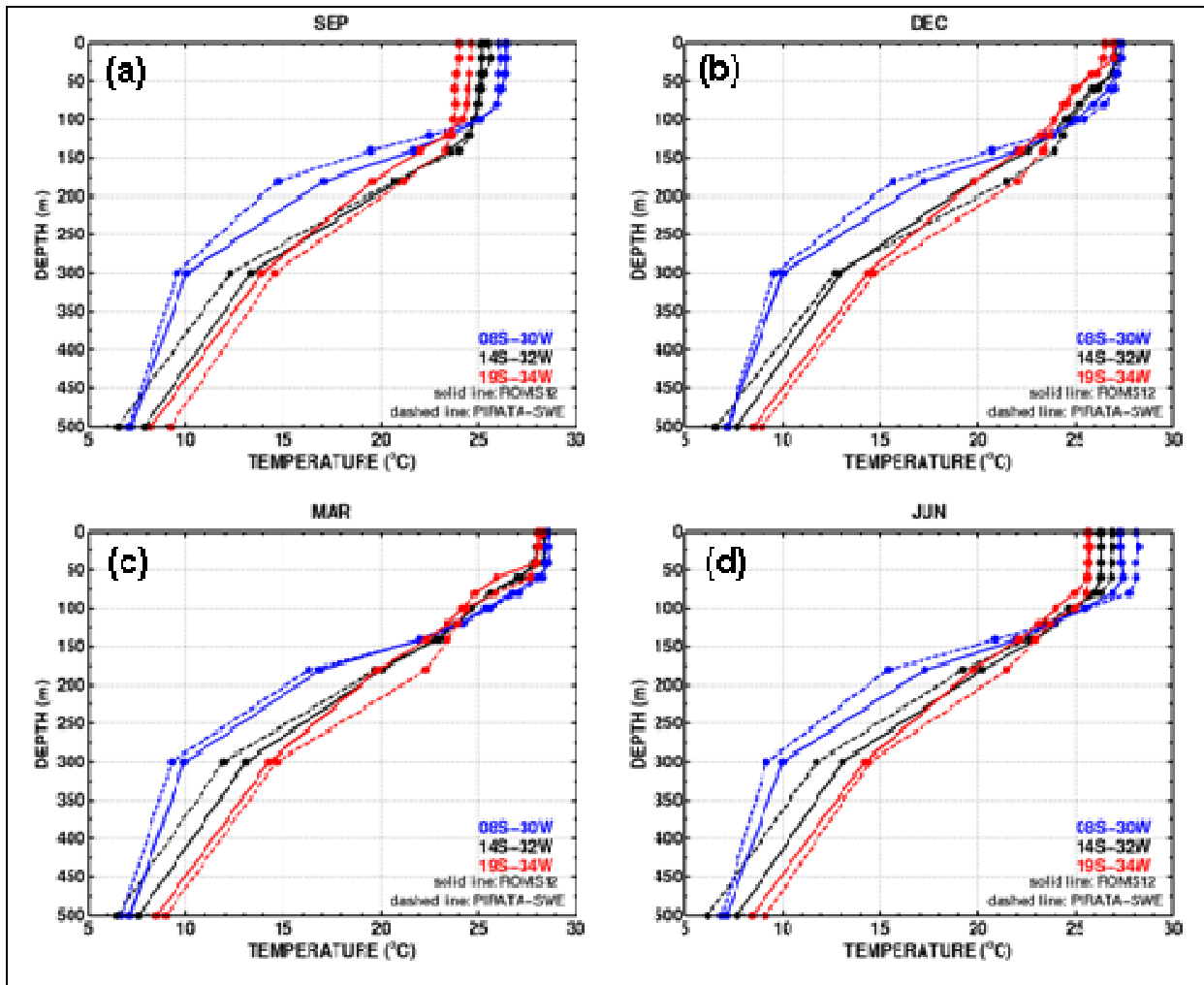

Figure 5. September (a), December (b), March (c) and June (d) monthly averaged vertical profiles of temperature $0-500 \mathrm{~m}$ at the three PIRATA-SWE sites provided by climatic ROMS and by PIRATA monthly averaged profiles from September 2005 to February 2008.

Seasonal evolutions of the heat content integrated inside the mixing layer (MLD defined as in Annex 1) are computed for the three PIRATA-SWE sites (Fig. 6) according to the ROMS climatic outputs (solid lines), and the in-situ PIRATA measurements from September 2005 to February 2008 (dashed lines). Like for the previous discussion about the thermal profile comparisons (Fig. 5), the agreement between simulation and observation is here also very satisfactory, especially for the site $14^{\circ} \mathrm{S}-32^{\circ} \mathrm{W}$, i.e. the centre of the PIRATA-SWE array, where both observed and simulated curves take very similar shapes. The two largest differences $\left(\sim 4 \times 10^{8} \mathrm{~J}^{\mathrm{m}} \mathrm{m}^{-2}\right)$, both indicating a greater observed value of heat content vs. the climatic simulation, are noted from February to June for the southern site, and from April to June for the northern site. 
SILVA; ARAUJO; SERVAIN; PENVEN. Circulation and heat budget in a regional climatological simulation of the Southwestern Tropical Atlantic.
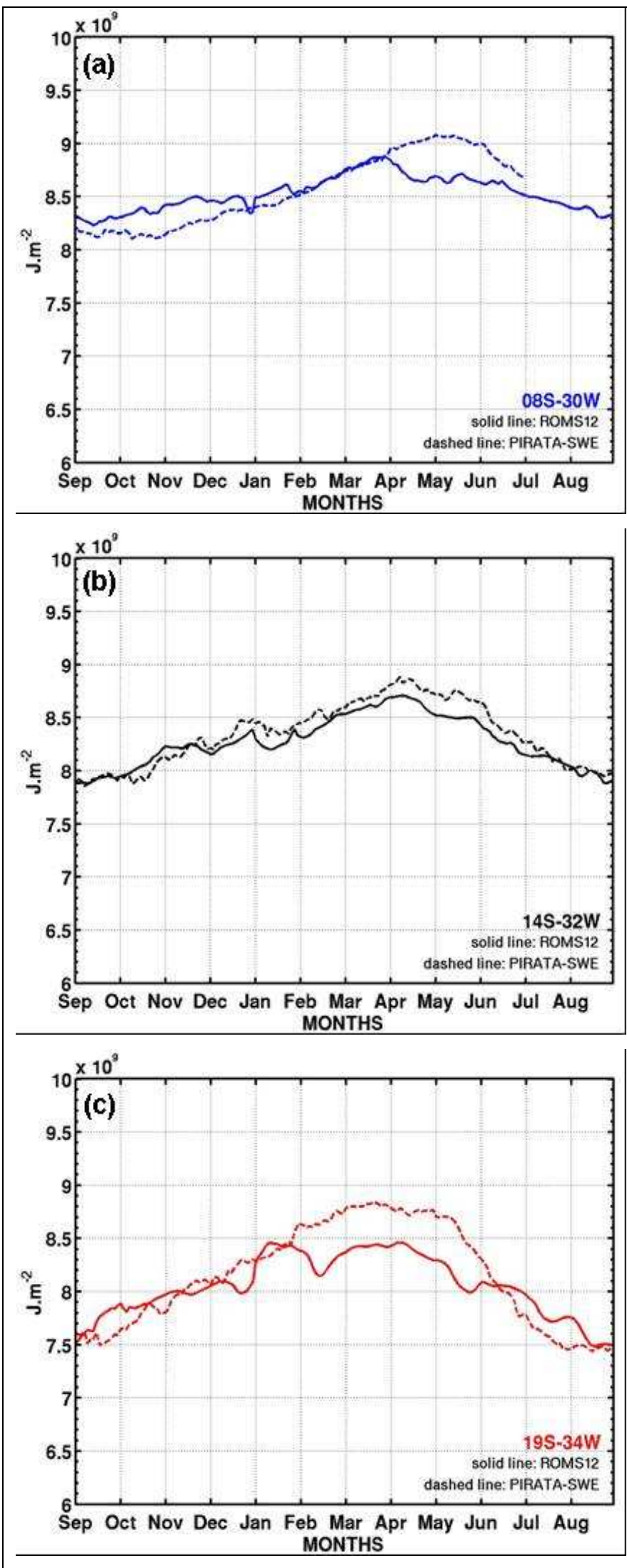

Figure 6. Comparison of temporal evolution of seasonal heat content in the mixed layer at $8^{\circ} \mathrm{S}-30^{\circ} \mathrm{W}$ (a), $14^{\circ} \mathrm{S}-32^{\circ} \mathrm{W}$ (b) and $19^{\circ} \mathrm{S}-34^{\circ} \mathrm{W}$ (c), provided by PIRATA in-situ observations (dashed line) and ROMS (solid line) for the period of September to August. 


\section{Oceanic dynamics vs. atmospheric forcing}

After checking ROMS abilities in reproducing the ocean thermodynamics in the study region, we are now using its results to test the relative influence of the ocean dynamics vs. the atmospheric forcing for settling the seasonal variation of the mixing layer temperature. For that, we continue to focus on the three PIRATA sites, now adding three other locations at the same latitudes as those of PIRATA sites, but along the Brazilian coast (see Fig. 1).

Considering the local heat budget inside the mixing layer, the different components of the temperature equation can be written as:

$$
\underbrace{\frac{\partial T}{\partial \mathrm{t}}}_{\text {LOCAL CHANGE }}+\underbrace{U_{j} \frac{\partial T}{\partial x_{j}}+\frac{\partial\left(\overline{u_{i}^{\prime} T^{\prime}}\right)}{\partial x_{j}}}_{\text {OCEAN (ADVECTION+DIFFUSION) }}-\underbrace{\Phi_{T}}_{\text {HEAT FLUX }}=0
$$

where $U_{i}$ is the mean velocity, T (or SST) is the temperature of MLD, and $\Phi_{T}$ is the total heat flux used to force the ROMS (Marchesiello et al., 2003).

Temporal changes of the three terms at left of Eq. 1 (in ${ }^{\circ} \mathrm{C} /$ Month), as well as $\mathrm{T}$ (in ${ }^{\circ} \mathrm{C}$ ), have been monthly integrated through MLD, and are presented in Fig. 7 for the three sites of PIRATA-SWE and the three coastal locations. A first overview indicates that the main seasonal behaviors of the dynamics are very similar in the whole domain, though we note somewhat larger amplitudes in higher latitudes than in equatorial areas, and along the coastline than in the open ocean. Highest $T$ (dotted black curves) values are centered about March (from $28.50^{\circ} \mathrm{C}$ in the northern locations, to $27.75^{\circ} \mathrm{C}$ in the southern locations), and coldest $\mathrm{T}$ values are centered about August-September (from $26.25^{\circ} \mathrm{C}$ in the north, to $24.00^{\circ} \mathrm{C}$ in the south). The seasonal change of temperature is roughly of sinusoidal type, except in the southern coastal site (Fig. 7e), located at the eastern limit of the coldest waters (see Figs. 2a,b), where $T$ undergoes a rapid reduction of half degree in November-December, thus slowing down the thermal increase between minimum $\left(\sim 24.8^{\circ} \mathrm{C}\right)$ in July-August and maximum $\left(\sim 28.0^{\circ} \mathrm{C}\right)$ in February-March. As related on Eq. 1 the local changes in $\mathrm{T}$ (continuous black curves on Fig. 7) result from the combination of net atmospheric forcing ("FLUX" in red) and net oceanic balance ("ADV+DIFF" in blue). In agreement with previous works (e.g. Carton \& Zhou, 1997), and except with the location $19^{\circ} \mathrm{S}-38^{\circ} \mathrm{W}$ which shall be discussed hereafter, local variations of $\mathrm{T}$ are mainly driven by the atmospheric forcing in the sense that positive (negative) values of $\frac{\partial T}{\partial t}$ generally occur during positive (negative) values of "FLUX". It is however interesting to note that, as opposed to what it was generally thought until now for this region, the net oceanic contribution evolve according to an amplitude of the same order of magnitude (until to about $3^{\circ} \mathrm{C} /$ Month, peak-to-peak) than the seasonal variations of atmospheric forcing.

The time duration of positive values of "FLUX", occurring mainly from AugustSeptember to March-April, (i.e. when South Hemisphere is warmer), is significantly longer than the duration of negative occurrences in May-June-July, i.e. when the sun is at its northern position. These time durations are slightly modulated according to latitude: close to equator the "FLUX" is positive during a longer period ( 8-9 months), while in the south of the study domain, positive and negative periods tend to be of equal duration ( 6 months). As another characteristic, the positive values of "FLUX" are generally of larger amplitude than the negative values. Consequently, in order to maintain the local equilibrium of $\frac{\partial T}{\partial t}$ (a longer duration associated with larger amplitudes) positive "FLUX" must thus be compensated by an inverse net oceanic contribution during the same periods. In fact, "ADV+DIFF" opposes to atmospheric forcing "FLUX" most of the time, with larger and longer negative values during the 
SILVA; ARAUJO; SERVAIN; PENVEN. Circulation and heat budget in a regional climatological simulation of the Southwestern Tropical Atlantic.

period August-September to March-April, and shorter and weaker positive values during the remainder of the year, centered around June. Additional analyses carried out from individual oceanic components (not shown here), and confirmed by results from another recent study (Servain \& Lazar, personal communication), bring some additional information: the cooling of the mixing layer by oceanic effect noted here in the whole region comes primarily from a mixing by vertical diffusion between MLD water and deeper colder waters, while the warming by oceanic effect mainly comes from horizontal advection and lateral diffusion.

Like a particular case, lets us return on the site $19^{\circ} \mathrm{S}-38^{\circ} \mathrm{W}$, in the southern studied region, close to the coastline. This is a complex region, where the interaction between southward Brazil Current and Vitoria-Trindade ridge during the austral summer, induces the formation of cyclonic thermocline eddies that trap cold waters from an extending upwelling regime north of Cabo Frio (Castelão et al., 2004; Campos, 2006).

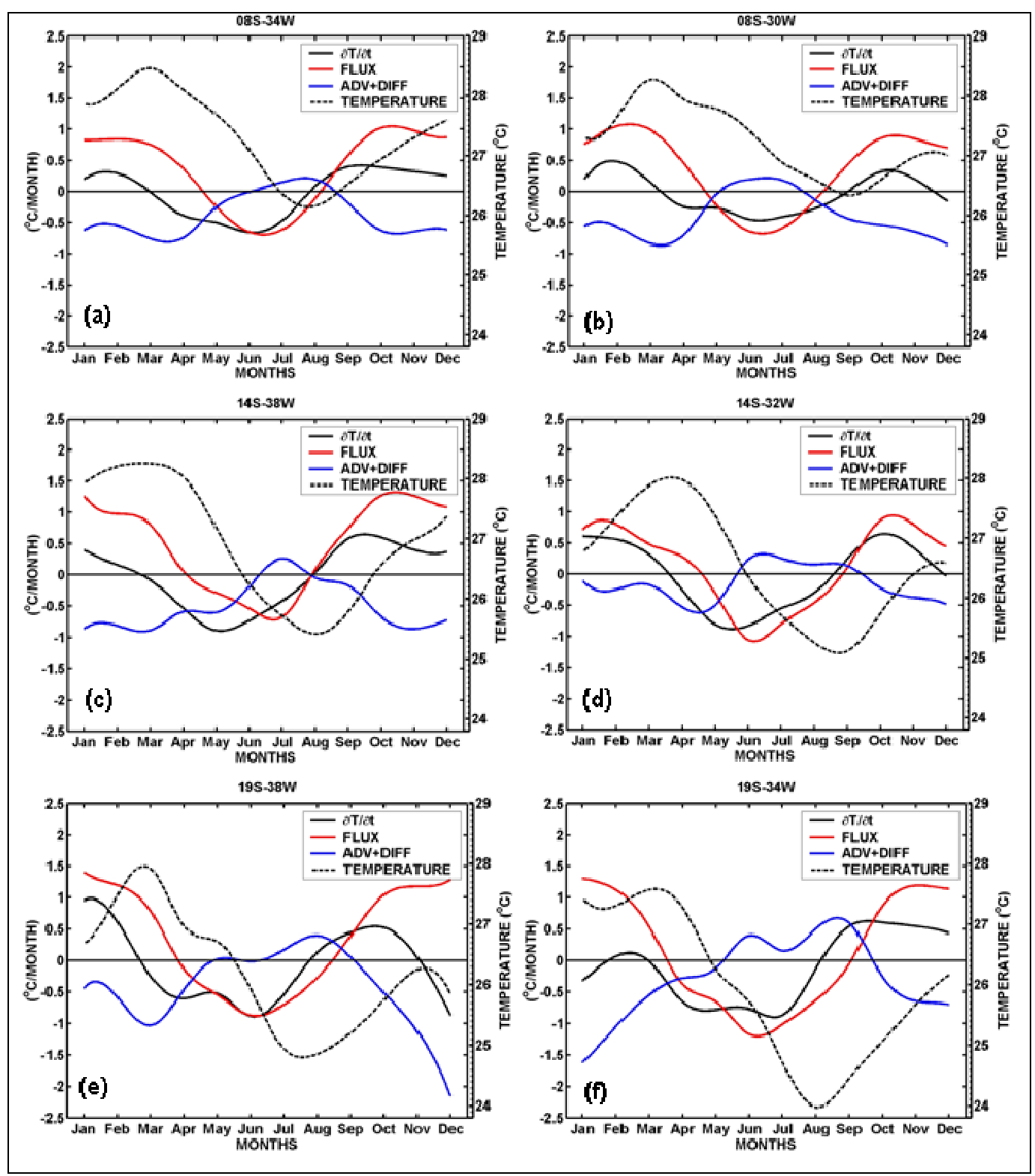

Figure 7. Seasonal evolution of MLD $\left({ }^{\circ} \mathrm{C}\right)$ (black dashed line), atmospheric (red line) and oceanic (blue line) contributions to the local change of MLD $\left({ }^{\circ} \mathrm{C} /\right.$ Month) (black continuous line) provided by ROMS at $8^{\circ} \mathrm{S}-34^{\circ} \mathrm{W}(\mathrm{a}), 8^{\circ} \mathrm{S}-30^{\circ} \mathrm{W}$ (b), $14^{\circ} \mathrm{S}-38^{\circ} \mathrm{W}$ (c), $14^{\circ} \mathrm{S}-32^{\circ} \mathrm{W}$ (d), $19^{\circ} \mathrm{S}-38^{\circ} \mathrm{W}(\mathrm{e})$ and $19^{\circ} \mathrm{S}-34^{\circ} \mathrm{W}(\mathrm{f})$ locations. 


\section{Mass transports across sections}

Mean (yearly averaged) meridional current and transport values obtained from the ROMS simulation along zonal sections $(0-1500 \mathrm{~m})$ at $8^{\circ} \mathrm{S}, 14^{\circ} \mathrm{S}$ and $19^{\circ} \mathrm{S}$ (i.e. the latitudes of the three PIRATA-SWE buoys) are presented in Fig. 8a,b,c. A fourth section (Fig. 8d) provides current and transport information within the $0-600 \mathrm{~m}$ across this mooring track. Three density levels are indicated on the plots. The $\sigma_{\mathrm{t}}=24.5 \mathrm{~kg} \cdot \mathrm{m}^{-3}$ separates the upper Tropical Surface Water (TSW) from the upper thermocline waters. The $\sigma_{\mathrm{t}}=26.8 \mathrm{~kg} \cdot \mathrm{m}^{-3}$ (at about $150 \mathrm{~m}$ depth) is the lower level of the water supplying the EUC (Schott et al., 1998). The $\sigma_{t}=32.15 \mathrm{~kg} \cdot \mathrm{m}^{-3}$ (at about $1100 \mathrm{~m}$ depth) indicates the lower boundary of the upper warmer waters as well as the lower boundary of the Antarctic Intermediate Water (AAIW). Bellow $1100 \mathrm{~m}$ depth we found the North Atlantic Deep Water (NADW) extending to about $4000 \mathrm{~m}$ depth $\left(\sigma_{t}=45.9 \mathrm{~kg} \cdot \mathrm{m}^{-3}\right)$. This is the layer where the Deep Western Boundary Current (DWBC) transports southward cold waters from the North Hemisphere.

The zonal sections (Figs. $8 a, b, c$ ) show a clear representation of the NBUC-NBC skirting the coastline from 100 to $1000 \mathrm{~m}$, with a northward transport increasing from $5.8 \mathrm{~Sv}$ at $19^{\circ} \mathrm{S}$ to $17.1 \mathrm{~Sv}$ at $8^{\circ} \mathrm{S}$. The site $8^{\circ} \mathrm{S}-34^{\circ} \mathrm{W}$ is located above the core of the NBUC which is situated at about $50 \mathrm{~km}$ from the coast, at 180 -to-500 m depth approximately (Silveira et al., 1994; Schott et al., 2002; Stramma et al., 2003; Schott et al., 2005). These results have been detected from field measurements. Stramma \& England (1999) showed from hydrographic data that the SEC bifurcation latitude is $16^{\circ} \mathrm{S}$ in near surface layer (top $100 \mathrm{~m}), 20^{\circ} \mathrm{S}$ in the layer $(100-500 \mathrm{~m})$ and $26^{\circ} \mathrm{S}$ in the AAIW (500-1200m). Wienders et al. (2000) also used hydrographic data to indicate that SEC bifurcation latitude is $14^{\circ} \mathrm{S}$ at the surface, $24^{\circ} \mathrm{S}$ in the $(400-500 \mathrm{~m})$ layer and around $26^{\circ} \mathrm{S}-28^{\circ} \mathrm{S}$ in the AAIW.

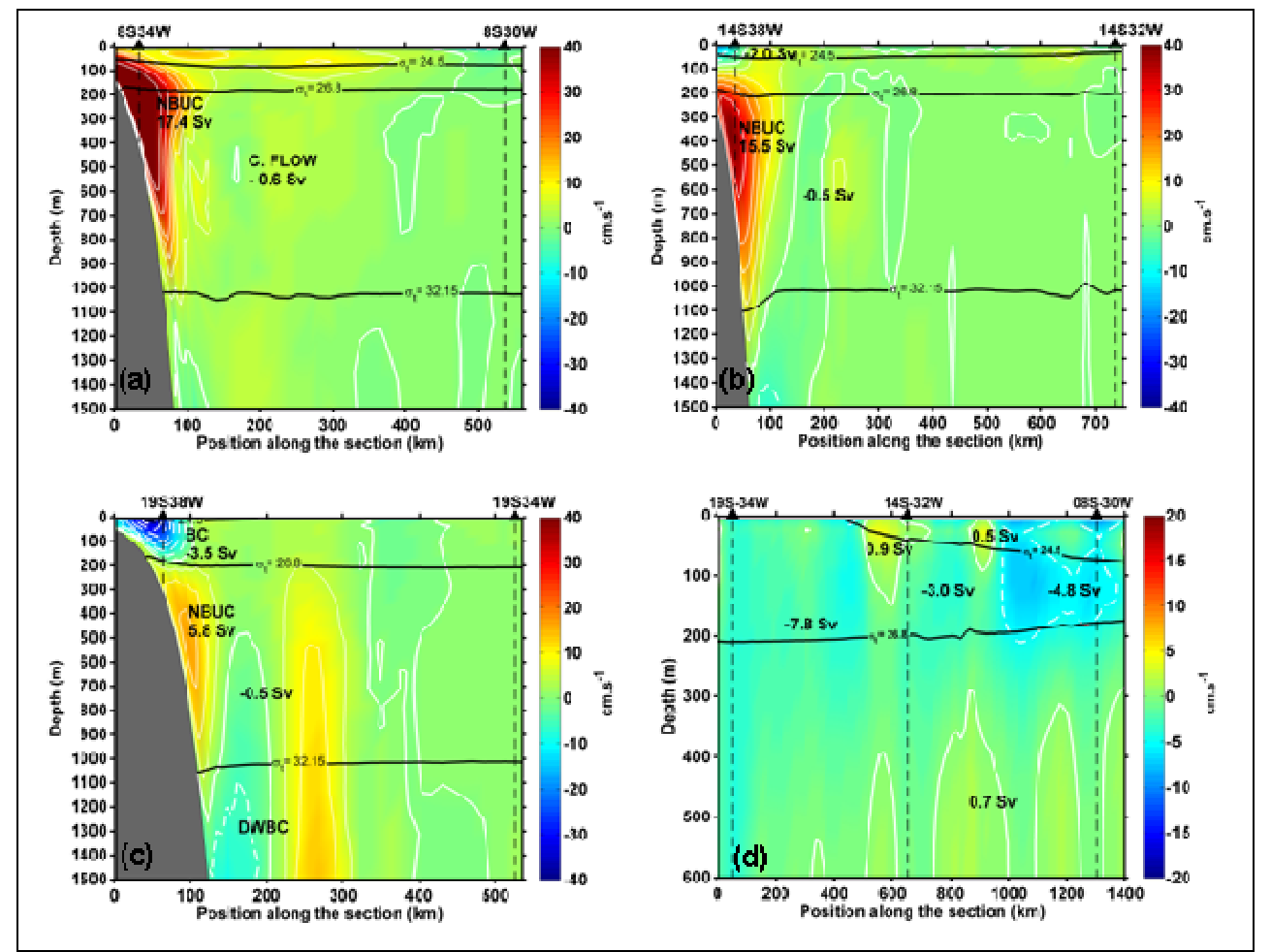

Figure 8. Mean annual volume transport averaged across three zonal sections at $8^{\circ} \mathrm{S}$ (a), $14^{\circ} \mathrm{S}$ (b) and $19^{\circ} \mathrm{S}$ (c), and across the section along the PIRATA-SWE array (d). Positive (negative) values indicated by solid (dashed) lines correspond to northward (southward) currents (panels $8 \mathrm{a}, 8 \mathrm{~b}$, and $8 \mathrm{c}$ ), while positive (negative) values indicated by solid (dashed) lines for the section along the PIRATA array correspond to eastward 
SILVA; ARAUJO; SERVAIN; PENVEN. Circulation and heat budget in a regional climatological simulation of the Southwestern Tropical Atlantic.

(westward) currents (panel 8d). The three horizontal solid black lines indicate the 24.5, 26.8 and 32.15 sigma-t values (in $\mathrm{kg} \cdot \mathrm{m}^{-3}$ ).

The ROMS results also agree with the numerical findings of Harper (2000), Malanotte-Rizzoli et al. (2000) and Rodrigues et al. (2007), indicating a poleward depth increasing of the SEC bifurcation along the Brazilian edge, as well as its seasonal variability: the SEC bifurcation reaches its southernmost position in July and its northernmost position in November (not shown here).

The flowing southward BC, confined to the shallow and near shore part of the Brazilian continental slope, is especially recognizable on the $19^{\circ} \mathrm{S}$ section (Fig. 8c) with southward transport of $3.5 \mathrm{~Sv}$. These numerical results were observed in previous studies. Miranda \& Castro (1981) identified the BC at $19^{\circ} \mathrm{S}$ as a surface narrow current ( $75 \mathrm{~km}$ ) limited to upper $500 \mathrm{~m}$ depth. Evans et al. (1983) indicate that BC keeps confined and organized above the continental shelf at $20.5^{\circ} \mathrm{S}$. The World Ocean Circulation Experiment (WOCE) current-moorings measurements obtained at $19^{\circ} \mathrm{S}$ pointed out a BC confined to the upper $200 \mathrm{~m}$ depth, with a mean southward velocity of approximately $15 \mathrm{~cm} \cdot \mathrm{s}^{-1}$ (Müller et al., 1998), same order found in our simulation.

The current and transport section along the PIRATA-SWE array (Fig. 8d) allows to get an idea of how the southern part of the SEC extends before to reach the western continental boundary. Indeed, we may note a succession of more powerful westward systems (one core with $4.8 \mathrm{~Sv}$, from 50 to $200 \mathrm{~m}$ depth, and with a 300-400 km width) and less powerful eastward systems (each one with a core less than $1.0 \mathrm{~Sv}$, from 0 to $100 \mathrm{~m}$ depth, and with a width lower than $100 \mathrm{~km}$ ). Let us note however that the most important westward transport of $7.8 \mathrm{~Sv}$ shallower $600 \mathrm{~m}$ between $19^{\circ} \mathrm{S}-34^{\circ} \mathrm{W}$ and $14^{\circ} \mathrm{S}-$ $32^{\circ} \mathrm{W}$ PIRATA sites has large extension with small velocity intensity values across the section Elsewhere in the deeper ocean the E-W transport given by the model results is relatively weak.

According to ROMS simulation, the annual-mean westward transport between $8^{\circ} \mathrm{S}$ $30^{\circ} \mathrm{W}$ and $19^{\circ} \mathrm{S}-34^{\circ} \mathrm{W}$ for the SEC is $15.6 \mathrm{~Sv}$ for the upper $600 \mathrm{~m}$, which is in good agreement with observations and previous numerical studies. For instance, Wienders et al. (2000) estimated a westward transport of 21.5 Sv for the SEC within the SACW layer between $7.5^{\circ} \mathrm{S}$ to $20^{\circ} \mathrm{S}$, while the hydrographic data of Stramma (1991) showed a westward SEC transport of about $20 \mathrm{~Sv}$ for this same region. Furthermore the recent numerical simulations of Rodrigues et al. (2007) indicated a annual-mean westward SEC transport between $6^{\circ} \mathrm{S}$ and $22^{\circ} \mathrm{S}$ (along the meridian $30^{\circ} \mathrm{W}$ ) of $18 \mathrm{~Sv}$.

\section{CONCLUSION}

The primary motivation of that study was to develop and validate a high-resolution regional oceanic model in the south-western tropical Atlantic. Until now, that region was poorly studied although it is of capital interest for the global ocean inter-hemispheric heat transport. In the shallow waters for instance, this is a region of divergence of the SEC who feeds many northward and southward currents all along the western boundary. This is also a region of complex links between climatic variability of SST, heat content of the upper layers, atmospheric convective systems and precipitation on the adjacent continent, especially on the Brazilian Northeast region.

We were particularly interested on evaluating the capacity for a new generation state-of-the-art ROMS on reproducing mean meso-scales oceanic dynamics (i.e. SST) as well as seasonal variations of local terms of heat budget, and annual transfer of oceanic masses. This first climatological analysis focus on opposed seasonal conditions (September, representative of austral winter, and March, representative of austral summer). After checking that ROMS makes it possible to apprehend correctly meso-scale phenomena illustrated by instant SST patterns, numerical temperature values issued from a climatic simulation were compared to vertical profiles obtained by the first-year available data coming from recent deployed PIRATA-SWE buoys. Simulated temperature and in-situ temperature data are very close all long the first $500 \mathrm{~m}$ depth, with similar seasonal variations in the vertical thermal gradient within the thermocline. 
Oceanic terms (advection + diffusion) responsible for the seasonal evolution of the heat budget inside the upper ocean mixed layer (MLD) was calculated from numerical outputs and compared with the atmospheric forcing balance. Local illustrations of these results are given for the PIRATA-SWE sites and along the western Atlantic Ocean boundary. It is confirmed that the atmospheric surface fluxes are the main forcing mechanism acting on the heat budget in upper ocean mixing layers. Nevertheless the oceanic contribution is also very important, and can balance the atmospheric forcing effect in the southern study region. During practically all year, the oceanic component acts as an inversed contribution of the atmospheric forcing. During the warm season, that corresponds for instance (i.e. positive effect of the atmosphere) to a relatively strong cooling of the mixing layer mainly by vertical diffusion through the thermocline from colder deeper waters, and, during the cold season (i.e. negative effect of the atmosphere) to a weaker warming of the surface waters, mainly by horizontal advection.

The first outputs of ROMS confirm the extreme complexity of the oceanic circulation in this area. This is obviously the case along the western edge of the continent where many alongshore currents coexist and can interact. As a new insight, we have also pointed out a certain complexity of this dynamics in the open ocean. This is for instance the case in the vicinity of the PIRATA-SWE array. Indeed, along the virtual track represented by the three PIRATA moorings (about $1400 \mathrm{~km}$ ), we highlighted not less than three westward currents and three eastward currents on a yearly average. Although the annual net mass transport across this PIRATA track is normally directed towards the west (15.6 Sv for the upper $600 \mathrm{~m}$, in agreement with early estimations), that indicates that it will not be possible to perform any geostrophic computations using only the density profiles measured by the PIRATA sites. This implies that for a continuously observation of the ocean dynamics in this area it will be necessary to implement the PIRATA network with other better adapted systems.

This primary study is very encouraging. This is the first time (to our knowledge) that a high-resolution regional ocean model is used for examining the thermal structure, the heat budget and the oceanic transport in this area off Brazil; hence the verified model adjustment to available field data seems to be promising. Three next approaches are as follows: (i) to use the ROMS forced by interannual boundary conditions in order to investigate the interannual variability in this region, what could be of an invaluable complement for future analyses in association with the PIRATA-SWE data set, (ii) to perform various numerical experiments testing more in details the dynamics of the region, what could be, for instance, an useful tool to estimate the dispersion of the tuna eggs and larvae in the divergence of SEC (Mullon et al., 2002; Hugget et al., 2003), and (iii) to improve the regional ocean-atmosphere coupled model as a system (Murtugudde et al., 1996; Vintzileos et al., 1999a, b; Davey et al., 2001; Lazar et al., 2005). A potential outcome of this last item is then the possibility of coupling the ROMS with a dynamically active regional atmospheric model, when SST, heat and freshwater fluxes are calculated from processes which couple inside the marine boundary layer. These studies are underway.

\section{ACKNOWLEDGEMENTS}

This work is part of the CNPq-IRD Project "Climate of the Tropical Atlantic and Impacts on the Northeast" (CATIN), CNPq Process 492690/2004-9. The first author wishes to thank CAPES/BRAZIL (Coordination for the Improvement of Higher Education Staff) for the scholarship support.

\section{REFERENCES}

BLANCK, H.F. -1999- Using TOPEX Satellite El-Niño altimetry data to introduce thermal expansion and heat capacity concepts in chemistry courses. Journal of Chemical Education, 76:1635-1646.

BOURLÈS B., BUSALACCHI, A. J., CAMPOS, E.,HERNANDEZ, F.,LUMPKIN, R., MCPHADEN, M. J., MOURA, A. D.,NOBRE, P., PLANTON, S., J., TROTTE, J. \& YU, L. -2008- The 
SILVA; ARAUJO; SERVAIN; PENVEN. Circulation and heat budget in a regional climatological simulation of the Southwestern Tropical Atlantic.

PIRATA Program: History, Accomplishments, and Future Directions. Bulletin of the American Meteorological Society (in press), doi: 10.1175/2008BAMS2462.1.

BRAINERD, K.E. \& GREGG, M.C. -1995- Surface mixed and mixing layer depths. DeepSea Research I, 42:1521-1543.

CAMPOS, E. J. D. -2006-The equatorward translation of the Vitoria eddy in a numerical simulation. Geophysical Research Letters, 33, L22607.

CARBONEL, C.A.A.H. -2003- Modelling of upwelling-downwelling cycles caused by variable wind in a very sensitive coastal system. Continental Shelf Research, 23:15591578.

CARTON, J. A. \& ZHOU, Z. -1997- Annual cycle of sea surface temperature in the tropical Atlantic Ocean. Journal of Geophysical Research, 102:27813-27824.

CASTELÃO, R. M., CAMPOS, E.J.D. \& MILLER, J. L. -2004- Coastal upwelling driven by wind and meanders of the Brazil Current. Journal of Coastal Research, 20:662-671.

CONKRIGHT, M. E., LOCARNINI, R. A., GARCIA, H. E., O'BRIEN T. D., BOYER, T. P., C. STEPHENS, C. \& ANTONOV, J. I. -2002- World Ocean Atlas 2001: Objective Analyses, Data Statistics, and Figures, CD-ROM Documentation, National Oceanographic Data Center, Silver Spring, MD.

DA SILVA, A. M., YOUNG, C. C. \& LEVITUS, S. -1994- Atlas of surface marine data 1994, Vol. 1, algotithms and procedures, NOAA Atlas NESDIS 6. U.S. Department of Commerce, NOAA, NESDIS, USA, 74 p.

DAVEY, M., HUDDLESTON, M., SPERBER, K., BRACONNOT, P., BRYAN, F. \& coauthors 2001- STOIC, a study of coupled model climatology and variability in tropical ocean regions. Climate Dynamics, 18:403-420.

EVANS, D. L., SIGNORINI, S. R. \& MIRANDA, L. B. -1983- A note on the transport of the Brazil Current. Journal of Physical Oceanography, 13:1732-1738.

FOLTZ, G., R. \& MCPHADEN, M.,J. -2006-. The Role of Oceanic Heat Advection in the Evolution of Tropical North and South Atlantic SST Anomalies. Journal of Climate, 19:6122-6138.

GODAE High Resolution Sea Surface Temperature Pilot Project - GHRSST-PP -2007http://www.ghrsst-pp.org/, on line dataset, 04 June 2007.

HAIDVOGEL, D. B., ARANGO, H. G., HEDSTRÖM, K., BECKMANN, A., MALANOTTERIZZOLI, P. \& SHCHEPETKIN, A. F. -2000-. Model evaluation experiments in the North Atlantic basin: simulations in nonlinear terrain-following coordinates. Dynamics Atmosphere and Oceans, 32:239-281.

HARPER, S. -2000- Thermocline ventilation and pathways of tropical-subtropical water mass exchange. Tellus, 52A:330-345.

HAYES, S. P., MANGUM, L. J., PICAUT, J., SUMI, A. \& TAKEUCHI, K. -1991- TOGA-TAO: A moored array for real-time measurements in the tropical Pacific Ocean. Bulletin of the American Meteorological Society, 72:339-347.

HUGGET, J. P., FREÓN, P., MULLON, C. \& PENVEN, P. -2003- Modelling the transport success of anchovy Engraulis encrasicolus eggs and larvae in the southern Benguela: The effect of spatio-temporal spawning patterns. Marine Ecology Progress Series, 250:247-262.

IKEDA, Y. \& STEVENSON, M. -1978- Time series analysis of NOAA-4 sea surface temperature (SST) data TOGA-TAO: A moored array for real-time measurements in the tropical Pacific Ocean. Remote Sensing of Environment, 7:349-362.

LARGE, W. G., McWILLIAMS, J. C. \& DONEY, S. C. -1994- Oceanic vertical mixing: a review and a model with a nonlocal boundary layer parametrization. Reviews in Geophysics, 32:363-403. 
LAZAR, A., VINTZILEOS, A., DOBLAS-REYES, F., ROGEL, P. \& DELÉCLUSE, P. -2005Seasonal forecast of tropical climate with coupled ocean-atmosphere GCMs: On the respective role of the atmosphere and the ocean model components in the drifting mean climate. Tellus, 57:387-397.

LUMPKIN, R. \& SPEER, K. -2003- Large-scale vertical and horizontal circulation in the North Atlantic ocean. Journal of Physical Oceanography, 33:1902-1920.

LUTJEHARMS, J. R. E., PENVEN, P. \& ROY, C. -2003- Modelling the shear edge eddies of the southern Agulhas Current. Continental Shelf Research, 23:1099-1115.

MCCREADY, P. \& GEYER, G. R. -2001- Estuarine salt flux through an isohaline surface. Journal of Geophysical Research, 106:11629-11637.

MALANOTTE-RIZZOLI, P., HEDSTRÖM, K., ARANGO, H. G. \& HAIDVOGEL, D. B. -2000Water mass pathways between the subtropical and tropical ocean in a climatological simulation of the North Atlantic. Dynamics of Atmosphere and Oceans, 32:331-371.

MARCHESIELLO, P., MCWILLIAMS, J. C. \& SHCHEPETIN, A. -2001- Open boundary conditions for long-term integration of regional oceanic models. Ocean Modelling, 3:120.

MARCHESIELLO, P., MCWILLIAMS, J. C. \& SHCHEPETIN, A. -2003-. Equilibrium structure and dynamics of the California Current System. Journal of Physical Oceanography, 33:753-783.

MILLER, J.R. -1976- The salinity effect ion a mixed layer ocean model. Journal of Physical Oceanography, 6:29-35.

MIRANDA, L. B. \& CASTRO, B. M. -1981- Geostrophic flow conditions of the Brazil Current at $19^{\circ} \mathrm{S}$. Ciência Interamericana, 22:44-48.

MOURA, A. \& SHUCKLA, J. -1981- On the dynamics of droughts in Northeast Brazil: Observations, theory, and numerical experiments with a general circulation model. Journal of Atmospheric Science, 38:2653-2675.

MÜLLER, T. J., IKEDA, Y., ZANGENBERG, N. \& NONATO, L. V. -1998- Direct measurements of the western boundary currents between $20^{\circ} \mathrm{S}-28^{\circ} \mathrm{S}$. Journal of Geophysical Research, 103:529-543.

MULLON, C., CURY, P. \& PENVEN, P. -2002- Evolutionary individual-based model for the recruitment of anchovy (Engraulis capensis) in the southern Benguela. Can. J. Fish. Aquat. Sci., 59:910-922.

MURTUGUDDE, R., SEAGER, R. \& BUSULACCHI, A. -1996- Simulation of the tropical oceans with an ocean GCM coupled to an atmospheric mixed-layer model. Journal of Climate, 9:1795-1815.

NOBRE, P., CAMPOS, E., POLITO, P. S., SATO, O. T. \& LORENZZETTI, J. A.-2005Brazilian proposal for a PIRATA-SW Extension. Scientific Rationale. 44 pp.

NOBRE, P., CAMPOS, E., SERVAIN, J. \& ARAUJO, M. -2008- The PIRATA South-West Extension: Scientific motivation, Realization and Perspectives (in preparation).

OHLMANN, J. C., SIEGEL, D. A. \& GAUTIER, C. -1996- Ocean mixed layer depth heating and solar penetration: A global analysis. Journal of Climate, 9:2265-2280.

PENVEN, P., ROY, C., COLIN DE VERDIÈRE, A. \& LARGIER, J. -2000- Simulation and quantification of a coastal jet retention process using a barotropic model. Oceanological Acta, 23:615-634.

PENVEN, P., LUTJEHARMS, J. R. E., MARCHESIELLO, P., ROY, C. \& WEEKS, S. J. -2001Generation of cyclonic eddies by the Agulhas Current in the lee of the Agulhas Bank. Geophysical Research Letters, 27:1055-1058. 
SILVA; ARAUJO; SERVAIN; PENVEN. Circulation and heat budget in a regional climatological simulation of the Southwestern Tropical Atlantic.

PETERSON R. G. \& STRAMMA, L. -1991- Upper-level circulation in the South Atlantic ocean. Progress in Oceanography, 26:1-73.

RAO, V. B., DE LIMA, M. C. \& FRANCHITO, S. H. -1993- Seasonal and inter-annual variations of rainfall over eastern Northeast Brazil. Journal of Climate, 6:1754-1763.

RODRIGUES, R. R., ROTHSTEIN, L. M. \& WIMBUSH, M. -2007- Seasonal variability of the South Equatorial Current bifurcation in the Atlantic ocean: A numerical study. Journal of Physical Oceanography, 37:16-37.

SCHOTT, F. A., FISCHER, J. \& STRAMMA, L. -1998- Transports and pathways of the upper-layer circulation in the western tropical Atlantic. Journal of Physical

Oceanography, 28:1904-1928.

SCHOTT, F. A., BRANDT, P., HAMANN, M., FISCHER, J. \& STRAMMA, L. -2002- On the boundary flow off Brazil at $5-10^{\circ} \mathrm{S}$ and its connection to the interior tropical Atlantic. Journal of Geophysical Research 29, doi: 10.1029/2002GL014786.

SCHOTT, F. A., DENGLER, M., ZANTROPP, R., STRAMMA, L., FISCHER, J. \& BRANDT, P. 2005- The shallow and deep western boundary circulation of the South Atlantic at $5^{\circ}-$ $11^{\circ} \mathrm{S}$. Journal of Physical Oceanography, 35:2031-2053.

SERVAIN J., BUSALACCHI, A., MOURA, A., MCPHADEN, A., REVERDIN, G., VIANNA, M. \& ZEBIAK, S. -1998- A Pilot Research Moored Array in the Tropical Atlantic (PIRATA). Bulletin of the American Meteorological Society, 79:2019-2031.

SHCHEPETKIN, A. F. \& MCWILLIAMS, J. C. -1998- Quasi-monotone advection schemes based on explicit locally adaptive dissipation. Monthly Weather Review, 126:1541-1580.

SHCHEPETKIN, A. F. \& MCWILLIAMS, J. C. -2005- The regional oceanic modeling system (ROMS): a split-explicit, free-surface, topography-following-coordinate oceanic model. Ocean Modelling, 9:347-404.

SHE, J. \& KLINCK, J. M. -2000- Flow near submarine canyons driven by constant wind. Journal of Geophysical Research, 105:28671-28694.

SILVEIRA, I. C. A., MIRANDA, L. B. \& BROWN, W. S. -1994- On the origins of the North Brazil Current. Journal of Geophysical Research, 99:22501-22512.

SMITH, W. H. F. \& SANDWELL, D. T. -1997- Global seafloor topography from satellite altimetry and ship depth soundings. Science, 277: 1957-1962.

SPALL, M. A., 1991. A diagnostic study of wind- and buoyancy- driven north Atlantic circulation. Journal of Geophysical Research, 96:18509-18518.

SPRINTALL, J. \& TOMCZAK, M. -1990- Salinity considerations in the oceanic surface mixed layer. Ocean Sciences Institute Rep. 36, University of Sidney, 170 pp.

SPRINTALL, J. \& TOMCZAK, M. -1992- Evidences of the barrier layer in the surface layer of the tropics. Journal of Geophysical Research, 97:7305-7316.

STRAMMA, L. -1991- Geostrophic transport of the South Equatorial Current in the Atlantic. Journal of Marine Research, 49:281-284.

STRAMMA, L., FISCHER, J. \& REPPIN, J. -1995- The North Brazil Undercurrent. Deep Sea Research I, 42:773-395.

STRAMMA, L. \& ENGLAND, M. -1999- On the water masses and mean circulation of the South Atlantic Ocean. Journal of Geophysical Research, 104:20863-20883.

STRAMMA, L., FISCHER, J., BRANDT, P. \& SCHOTT, F. -2003- Circulation, variability and near-equatorial meridional flow in the central tropical Atlantic. In: Interhemispheric Water Exchanges in the Atlantic Ocean (G. J. Goni \& P. Malanotte-Rizzoli, eds). Elsevier. B.V., 1-22. 
VINTZILEOS, A., DELÉCLUSE, P. \& SADOURNY, R. -1999a- On the mechanisms in a tropical ocean-global atmosphere coupled general circulation model. Part I: Mean state and the seasonal cycle. Climate Dynamics, 15:43-62.

VINTZILEOS, A., DELÉCLUSE, P. \& SADOURNY, R. -1999b- On the mechanisms in a tropical ocean-global atmosphere coupled general circulation model. Part II: Interannual variability and its relation to the seasonal cycle. Climate Dynamics, 15:63-80.

WIENDERS, N., ARHAN, M. \& MERCIER, H. -2000- Circulation at the western boundary of the south and equatorial Atlantic. Journal of Marine Research, 58:1007-1039.

\section{ANNEX 1}

Most criteria used for determining MLD in the ocean require the deviation of the temperature $T$ (or density, $\sigma_{t}$ ) from its surface value to be smaller then a certain fixed value (Sprintall \& Tomczak, 1990; Brainerd \& Gregg, 1995). MLD is estimated as the depth where density is equal to the sea surface value plus an increment $\Delta \sigma_{\mathrm{t}}$ equivalent to a desired net decrease in temperature. For instance, Miller (1976) and Spall (1991) use $\Delta \sigma_{t}=0.125 \sigma_{t}(0)$ for determining mixed layer depth, while Sprintall \& Tomczak (1992) and OhImann et al. (1996) adopt $\Delta \sigma_{t}=0.5^{\circ} \mathrm{C}\left(\partial \sigma_{t} / \partial \mathrm{T}\right)$, where $\partial \sigma_{t} / \partial \mathrm{T}$ is the coefficient of thermal expansion. Following Sprintall \& Tomczak (1992), we evaluate in this paper MLD in terms of temperature and density steps $\left(\Delta \mathrm{T}=0.5^{\circ} \mathrm{C}\right.$ and $\Delta \sigma_{\mathrm{t}}=0.5^{\circ} \mathrm{C}\left(\partial \sigma_{\mathrm{t}} / \partial \mathrm{T}\right)$ ) from the sea surface temperature and density $\left(\mathrm{T}(0)\right.$ and $\sigma_{\mathrm{t}}(0)$ ) obtained from PIRATA and ROMS profiles:

$$
M L D=z\left(\sigma_{t}=\sigma_{t}(0)+\frac{\partial \sigma_{t}}{\partial T} \Delta T\right)
$$

where $\partial \sigma_{t} / \partial \mathrm{T}$ is calculated as a function of the surface temperature and salinity (Blanck, 1999). The heat content integrated inside the mixing layer (MLD) in each PIRATA site is estimated from field measurements and model results as follows:

$$
H C=\int_{M L D}^{0} \rho(z) \operatorname{cp}(z) T(z) d z
$$

where $\mathrm{HC}$ is the heat content $\left(\mathrm{J} \cdot \mathrm{m}^{-2}\right), \rho(\mathrm{z})$ is the sea water density $\left(\mathrm{kg} \cdot \mathrm{m}^{-3}\right), \mathrm{cp}(\mathrm{z})$ is

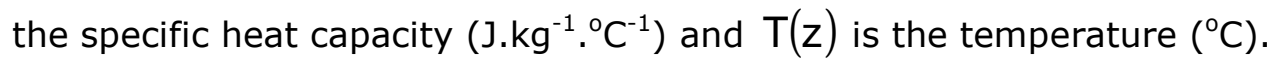

